\title{
Five Fragmentary Inscriptions from Assos
}

\author{
Tolga ÖZHAN*
}

All five fragmentary inscriptions presented in this paper are from the Assos excavation depository. Of these, the first, second and fourth inscriptions were already in the depository when the new excavation season began under the direction of Professor Nurettin Arslan in 2006. It is noted in the record sheet for the find, that the first fragment was discovered in the seventh seating section of the media cavea during excavations conducted in the Assos theater at the end of February 1996. It is likely that this fragment had fallen from the upper terrace, where the agora and bouleuterion of the ancient city were situated. There is no record in the archive about the find-spots of the second and fourth inscriptions. These two artifacts were probably found in the vicinity of Assos and moved to the depository in order to preserve them. The third fragment was discovered in 2007 in a trench located northeast of the burial enclosure thought to belong to the Larichos family, in the western necropolis of the city. The fifth fragmentary inscription was found in Çamköy, a village located northeast of Gülpınar, by Dr. Beate Arslan-Böhlendorf in the course of an archaeological field survey in 2013.

\section{No. 1. Fragment of Decree Honoring Latimos, Son of Cleomortos}

This is a fragment of a stele of white marble which is broken at the top, and bottom and down the right-hand side. The left side of the stele is intact. There is a fragmentary wreath decoration on the upper right rim. The stele is $0.215 \mathrm{~m}$ high, $0.148 \mathrm{~m}$ wide and $0.067 \mathrm{~m}$ deep. The height of the letters varies from $0.005 \mathrm{~m}$ to $0.011 \mathrm{~m}$. The inscription consists of three lines (fig. 1).

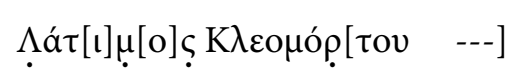

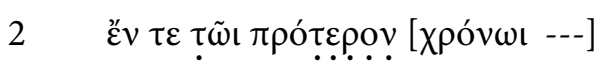

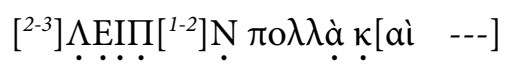

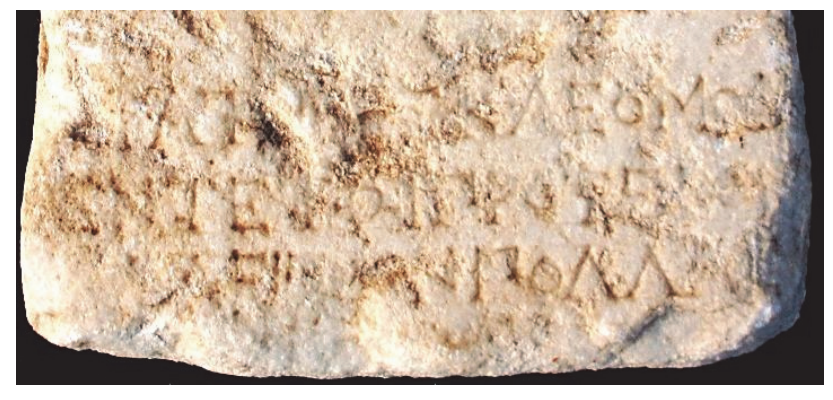

It is clear that this fragmentary inscription contains the surviving lines of the preamble of a decree honoring Latimos, son of Cleomortos, whose name is presented in the nominative in the first line of the fragment. Undoubtedly, this Latimos, son of Cleomortos, is same with Latimos, son of Cleomortos, from Assos, epigraphically attested in a Hellenistic honorary decree (for which the preamble is missing), through which several honors are bestowed on him by an unnamed city for his services as a judge alongside Echelaos, son of Athenagoros, who also served as a judge, and

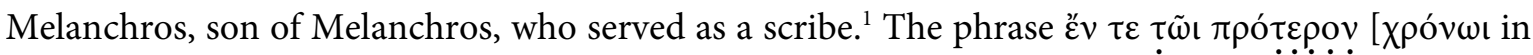
line two of the Assos inscription, which also appears in various forms elsewhere (e.g. $\check{\varepsilon} v \tau \varepsilon \tau \tilde{\omega} \iota$

* Dr. Tolga Özhan, Çanakkale Onsekiz Mart Üniversitesi, Fen-Edebiyat Fakültesi, Arkeoloji Bölümü 17100 Çanakkale (tolgaozhan@comu.edu.tr).

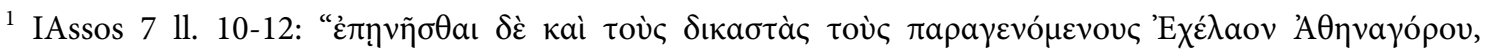

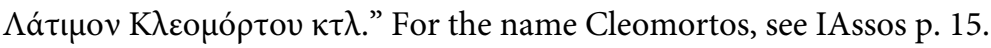




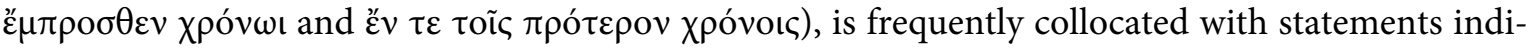

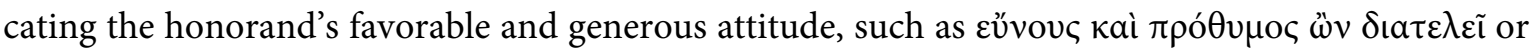

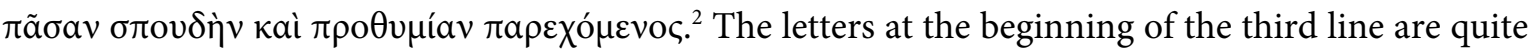
indistinct due to the badly abraded surface of the stone. Even though the temptation might be to restore the corrupted part with the participle $[\dot{\varepsilon} \lambda] \lambda \varepsilon_{. . .} \pi[\omega] \underline{\nu}$, which is often preceded by such phrases

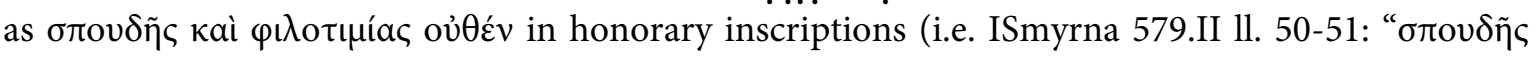

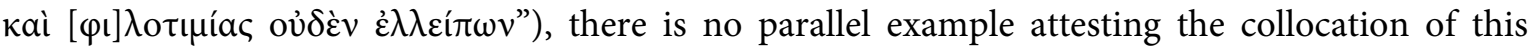
phrase with $\tilde{\varepsilon} v \tau \varepsilon \tau \tilde{\omega} \iota \pi \rho$ ó $\varepsilon \rho \rho \circ \chi \chi \rho o ́ v \omega \iota$ in the same text. A more plausible suggestion in terms of restoration is that the damaged part may have comprised the ethnikon of a city which was favored

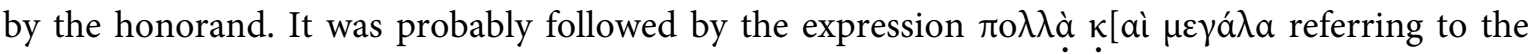
deeds of the honorand. ${ }^{3}$

It is unlikely that this fragment is a piece of the missing preamble of the aforementioned Hellenistic honorary decree that names Latimos, son of Cleomortos, since the letter forms of the two inscriptions are quite different. For instance, in this fragment $p i$ has a shorter vertical right stroke and omicron is smaller. It is possible to ascribe approximately the same date to this fragment, ca. 100 $\mathrm{BCE}$, as suggested for the Hellenistic inscription.

\section{No. 2. Cillaios}

This small block of gray marble is the preserved right front corner of a low pediment. It is broken off on the left-hand side and on the back. The height of the block is intact. The façade is decorated with a fine, smooth garland in recurrent motif with two rosettes below. The garland decoration continues on the right-hand side of the stone but with only one rosette preserved. The block measures $0.20 \mathrm{~m}$ wide, $0.152 \mathrm{~m}$ deep, and $0.169 \mathrm{~m}$ high. The height of the letters varies from $0.01 \mathrm{~m}$ to $0.014 \mathrm{~m}$. The inscription engraved in the space above the garland relief on the façade (fig. 2), is:

$[---] \mu \varepsilon ı \alpha$ Kı $\lambda \lambda \alpha^{\prime} \omega \iota \iota^{v a c .}$

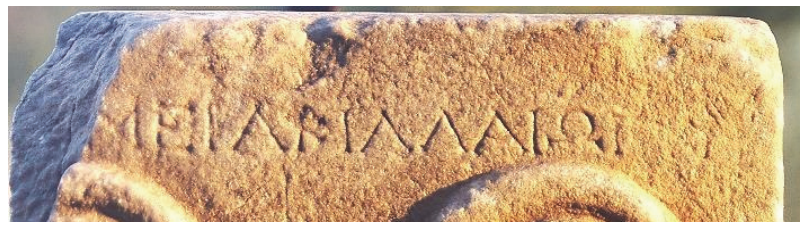

It is difficult to tell whether this fragment is the epitaph of an individual called Cillaios (since this name was attested as a personal name in Athens ${ }^{4}$ ), or a dedication to Apollo Cillaios. The fragmentary [---] $\mu \varepsilon ı \alpha$ at the beginning might be a patronymic adjective referring to the dedicant. Filiation through a patronymic adjective is frequently found in inscriptions from Assos. ${ }^{5}$

As Strabo (13.1.62) testifies, Kı $\lambda \lambda$ aĩo was an epithet of Apollo who was originally worshipped in Cilla, a place near Thebe and Chrysa. ${ }^{6}$ The only alleged epigraphic evidence for the cult of Apollo Cillaios is from Sestos in Thracian Chersonese. When accepting the word 'Cillaios' as a certain ref-

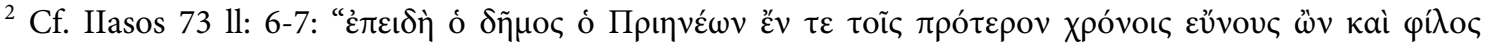

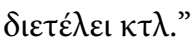

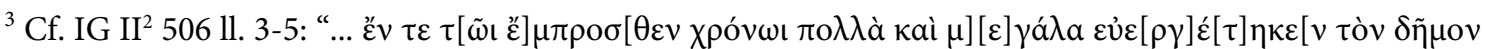

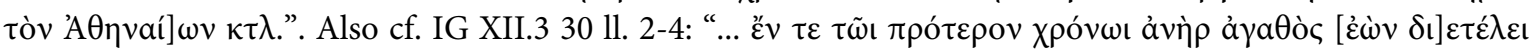

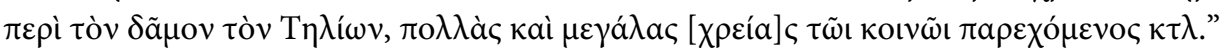

${ }^{4}$ Agora XV 206 (SEG 16, 91) = LGPN II s.v.

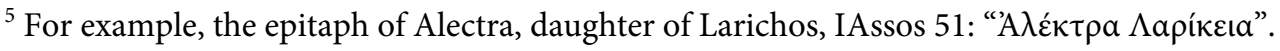

${ }^{6}$ For the site of Cilla, see IAdramytteion p. 31-33.
} 
erence to Apollo Cillaios in his discussion of the dating formula of a Hellenistic honorary decree

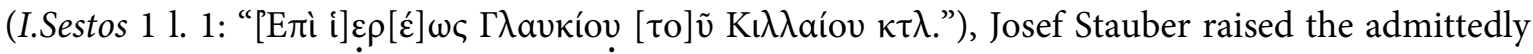
weak possibility that the cult of Apollo Cillaios in Cilla may have been transferred to Sestos. ${ }^{7}$ Nevertheless, it seems more likely that the word 'Cilliaos' in the Sestos inscription was the patronymic of the priest Glaucos rather than the epithet of Apollo. ${ }^{8}$

There is no substantial testimony as yet that refers to a cult of Apollo in the vicinity of Assos. ${ }^{9}$ In addition, due to the lack of information about the original site of our fragment, for now it is best not to treat this fragment as evidence for the presence of an cult of Apollo Cillaios in the city of Assos. The letter forms suggest that this fragment dates from the second century BCE.

\section{No. 3. Epitaph}

This fragment is a block of gray marble with upper and lower moldings. The right-hand side is damaged and the upper right corner has broken away. The rectangular fragmentary mortise on the top suggests that this was the low base of a slab stele. ${ }^{10}$ On the bottom of the block, there is a small square hollow to fasten it to the ground. The upper molding of the block is $0.315 \mathrm{~m}$ wide. The shaft's preserved width is $0.297 \mathrm{~m}$, and is $0.292 \mathrm{~m}$ deep. The preserved width of the lower molding is $0.315 \mathrm{~m}$ and it is $0.31 \mathrm{~m}$ deep. The total height of the base is $0.23 \mathrm{~m}$. The height of the letters varies from $0.014 \mathrm{~m}$ to $0.027 \mathrm{~m}$. The second line is indented, possibly to align with the length of the first line (fig. 3).

$$
2 \quad \text { Ало } \lambda \lambda[--------]
$$

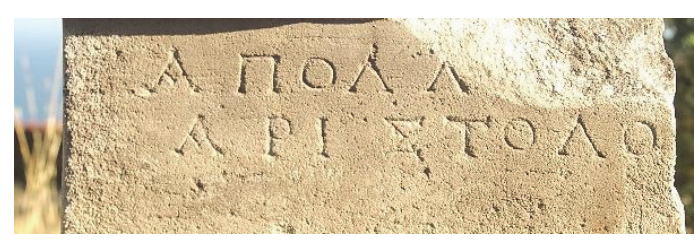

Taking into account the find-spot of the stone, this fragment seems to be a gravestone. As for the restoration of the theophoric name in the first line, which begins 'A $\pi$ o $\lambda \lambda$-, possibilities include Apollonios $^{11}$, Apollonophas ${ }^{12}$, Apollodoros ${ }^{13}$, Apollonides ${ }^{14}$ and Apollas ${ }^{15}$, which are epigraphically attested from Assos during the periods from fourth/third BCE to first century CE. The name in the

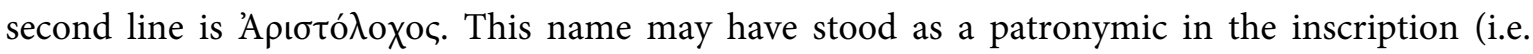

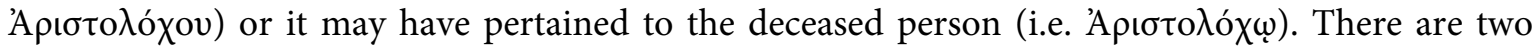
attestations of this name from Assos. One is a son of Euagoras, recorded on a large block thought to date from the fourth/third century B.C.(?), which was found in the necropolis of Assos. ${ }^{16}$ The other

\footnotetext{
${ }^{7}$ IAdramytteion p. 32-33.

${ }^{8}$ See LGPN IV s.v. Kı入入аĩoc.

${ }^{9}$ For theophoric names from Assos, derived from Apollo, see inscription no. 3 in this paper.

${ }^{10}$ For another low base supporting its inscribed stele found in the western necropolis of Assos, see Stupperich 1992, 8 and Tafel 6, no. 3 and 5.

${ }^{11}$ IAssos 21a = LGPN VA s.v. (no. 1309).

${ }^{12}$ Abmeier 1990, 25-26 no. 3 (SEG 40, 1112.3) = LGPN VA s.v.

${ }^{13}$ Abmeier 1990, 26 no. 5 (SEG 40, 1112.5) = LGPN VA s.v. (no. 305).

${ }^{14}$ Klee 1918, p. 16 no. IIC 1. 85 = LGPN VA s.v. (no. 244).

${ }^{15}$ LGPN VA s.v. (no. 106).

${ }^{16}$ Stupperich 1993, 3 (SEG 43, 875) = LGPN VA s.v. (no. 10).
} 
is a father of Anodicos the younger, recorded in a decree from Ilion concerning the organization of a festival. ${ }^{17}$

\section{No. 4. Dedication to Isis}

This is a round pedestal of gray marble with mortises on the top. The diameter of the pedestal measures $0.335 \mathrm{~m}$ and its preserved height is $0.113 \mathrm{~m}$. The height of the letters varies between 0.018 $\mathrm{m}$ and $0.026 \mathrm{~m}$. The inscription consists of two lines. The indented second line was engraved on the lower concave surface of the pedestal. The letters $\mathrm{M}, \mathrm{H}$ and $\mathrm{N}$ are ligatured (fig. 4 and 5). The fragment is as follows:

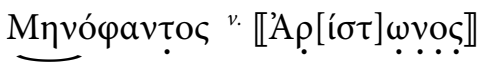

$$
\begin{aligned}
& \text { El̋ } \sigma ا \delta \iota^{v a c .} \text { A...[ }{ }^{c a .5} \text { ] }
\end{aligned}
$$

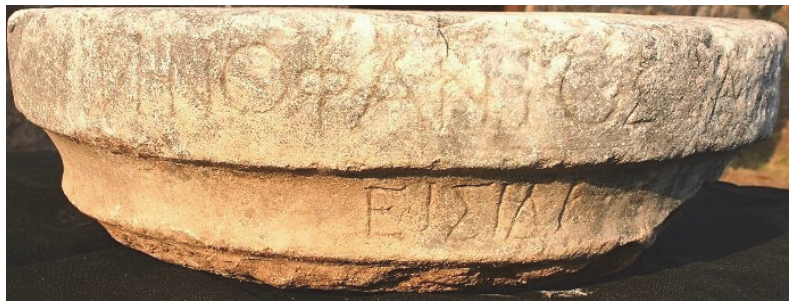

This is a dedication offered to Isis by Menophantos whose father's name, Ariston, was deliberately defaced. ${ }^{18}$ Bearing in mind the nature of this inscription, the missing part of line two could presumably be restored as åvé $[\theta \eta \kappa \varepsilon v]$. This dedication is the first convincing evidence of the existence of an Isis cult in the ancient city of Assos. Prior to this inscription, a citizen of Assos called Isidoros, a theophoric name derived from Isis, was found recorded in a proxenoi list, dating to ca. 150 BCE, from Delphi. ${ }^{19}$

There is another unpublished inscription from Assos that suggest the likely existence of an Egyptian cult. As recorded in the document archive of the findings, the following inscription was discovered in 1993. It is located on the seventh row of seating in the third cuneus of the summa cavea of the Assos theater. It was engraved across two blocks next to the stairway separating the third cuneus from the fourth. The total length of the two blocks bearing the inscription measures $2.60 \mathrm{~m}$. The last alpha stands separately in the middle of the second block. The height of the letters is between $0.16 \mathrm{~m}$ and $0.24 \mathrm{~m}$. The inscription is as follows (fig. 6):

\section{ऽЕРАПІА}

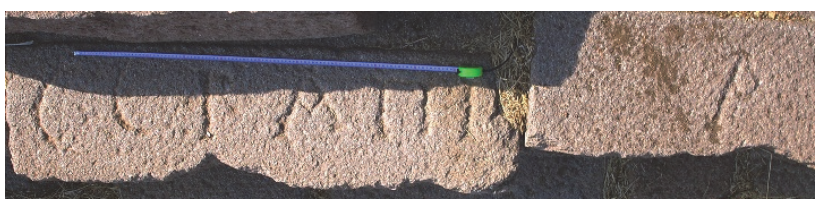

It is reasonable to assume that SERAPIA may have been the abbreviated form of the term $\sum \varepsilon \rho \alpha \pi \iota \alpha \sigma \tau \alpha i / \sum \varepsilon \rho \alpha \pi \iota \alpha \tau \tau \tilde{\omega} v$ indicating that the reserved seats were for the association of devotees of Sarapis (Sarapiastai). ${ }^{20}$ While no other epigraphic example of this abbreviation for Sarapiastai has, thus far, been attested, inscriptions on the seats of the Termessos theater in Pisidia, referring to the guild of "stone-masons from mountains" clearly demonstrate that uncommon abbreviations could

\footnotetext{
${ }^{17}$ IIlion 10 1. 9 = LGPN VA s.v. (no. 11).

${ }^{18}$ For other individuals from Assos bearing the name Ariston, see Breccia 1911, 128 no. 233: "Фı[ $\left.\lambda\right] \omega \omega^{2} \alpha \varsigma$

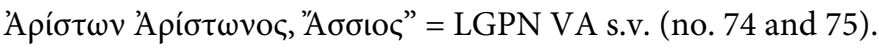

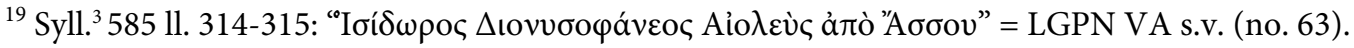

${ }^{20}$ For other place inscriptions of occupational guilds from the Assos theater, see Arslan - Özhan 2013, 7380.
} 
be used in such circumstances. ${ }^{21}$ Sarapiastai are attested in both Athen $s^{22}$ and Rhamnous ${ }^{23}$ in mainland Greece as well as on several Aegean islands, such as Thasos ${ }^{24}, \operatorname{Delos}^{25}, \mathrm{Ceos}^{26}$, Rhodes ${ }^{27}$ and $\operatorname{Lindos}^{28}$, including the city of Kamiros ${ }^{29}$ on Rhodes. A Hellenistic inscription from Methymna on the island of Lesbos, situated across the bay from Assos, also lists the names of Sarapiastai who promised to contribute to the association for the banquet at the megala Sarapieia. ${ }^{30}$ Prior to the discovery of the seating inscription in the Assos theater, the only attestation of Sarapiastai in Asia Minor comes from Limyra in Lycia. This is a dedication to Sarapis offered by one individual and the thiasos of Sarapiastai. ${ }^{31}$

A parallel example of seats reserved for a cult association is presented in CIL XII 714, a seating inscription of the association of pastophori of the Isis temple. The pastophori were placed next to the scholastici above the second-level walkway in the amphitheater of Arelate in Gallia Narbonensis. ${ }^{32}$ The length of the seats bearing the inscription in the Assos theater suggests that the association of Sarapiastai probably comprised only a small group of people. Both inscriptions from Assos belong to the Roman imperial period.

Compared with other regions in Asia Minor, the evidence indicating the presence of Egyptian cults in the Troad is very scarce. However, four examples are worth mentioning. In the ancient city of Scepsis, a fragmentary dedication to Sarapis, Isis and Anubis, and a coin of Faustina the Younger depicting Isis-Aphrodite with Eros-Harpocrates on its reverse, confirm the presence of Egyptian cults in the Troad..$^{33}$ The cults of Isis and Sarapis are epigraphically attested in the Propontic city of Parion..$^{34}$ Laurent Bricault also mentions two coins from Tenedos and Abydos both bearing a basileion figure, as evidence of an Egyptian cult. ${ }^{35}$

\section{No. 5. Honor to Lucius Calventius Faustinus, Winner of the Smintheia Pauleia Games}

This fragmentary piece of bluish-gray marble is damaged on all sides. Its current height is $0.38 \mathrm{~m}$, its width $0.41 \mathrm{~m}$ and its depth $0.12 \mathrm{~m}$. The size of the letters in line two is distinctly larger than the rest. The height of the letters is between $0.035 \mathrm{~m}$ and $0.097 \mathrm{~m}$, with the exception of the minuscule

${ }^{21}$ TAM III 872 A IX 30: “O $\rho(\rho \varepsilon \omega v) \lambda \alpha(\tau u ́ \pi \omega v)$.| $\kappa \tau \lambda$.” For the stone-cutters from Termessos, see also Brandt 1992, 137; van Nijf 1997, 225.

${ }^{22}$ IG II $^{2} 1292$ (SIRIS 2; RICIS 101/201).

${ }^{23}$ RICIS 101/0502.

${ }^{24}$ IG XII Suppl. 365 (SIRIS 265; RICIS 201/0101).

${ }^{25}$ IG XI.4 1226 (RICIS 202/0135); IG XI.4 1307 (RICIS 202/0191).

${ }^{26}$ IG XII.5 606 (SIRIS 158; RICIS 202/0801).

${ }^{27}$ IG XII.1 162 (SIRIS 176; RICIS 204/0105).

${ }^{28}$ SIRIS 236 and 238-239; RICIS 204/0338 and 204/0340-341.

${ }^{29}$ SIRIS 195-197; RICIS 204/0215-0217.

${ }^{30}$ IG XII.2 511 (SIRIS 262; RICIS 204/0401).

${ }^{31}$ RICIS II 306/0601.

${ }^{32}$ For the association of pastophori of the Isis Temple from Arelate, see also van Nijf 1997, 234.

${ }^{33}$ Judeich 1898, 237 fn. 3; SNG Troas-Aeolis-Lesbos, no. 1581 (RICIS II 301/1001). However, Françoise Dunand $(1973,100 \mathrm{fn} .1)$ casts doubt on the representation of Isis on the coin.

${ }^{34} \mathrm{Ful} 2009,101$. For the figure of sistrum on a coin from Parion, see RICIS II 301/0700.

${ }^{35}$ RICIS II 301/0800 (Tenedos) and 301/0900 (Abydos). 
iota, which was placed under alpha in the word $\pi \alpha i[\delta \omega v]$ in line three. Five lines have survived from the inscription (fig. 7):

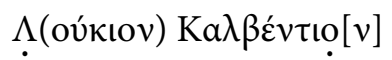

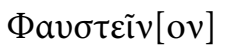

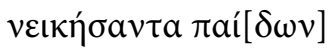

$$
\begin{aligned}
& {[\pi] \alpha v \kappa \rho a ́ \tau ı o v ~ \Sigma[\mu i ́ v]-}
\end{aligned}
$$

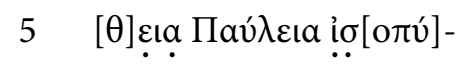

$$
\begin{aligned}
& {[\theta ı a}
\end{aligned}
$$

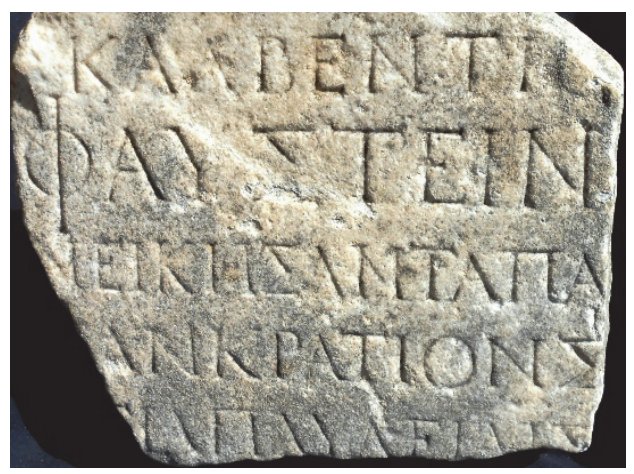

This fragment is the beginning of an honorary inscription for an athlete, Lucius Calventius Faustinus, who won the boys' pankration in the Smintheia Pauleia Games. It is well known that the Smintheia Pauleia games were held by the city of Alexandreia Troas in honor of Apollo Smintheus, whose sanctuary, named the Smintheion, lies close to the modern village of Gülpınar. There are, so far, only three known inscriptions, recording the Smintheia Pauleia games, and all pertain to the third century CE. ${ }^{36}$

The phraseology of this fragmentary inscription is almost identical to other honorary inscriptions mentioning Smintheia Pauleia. The first two lines contain the nomenclature of the victorious athlete, followed by the term indicating the athletic event and the name of the festival. ${ }^{37}$

This is the first attestation of the nomen Calventius in the vicinity of Alexandreia Troas/Colonia Augusta Troadensis. This nomen rarely appears in Asia Minor. Another individual bearing this nomen was a veteran, Calventius Silvanus, recorded in an epitaph from Anazarbos in Cilicia. ${ }^{38}$

Along with the boys' pankration, wrestling (pale) was another athletic event in the Smintheia Pauleia games. ${ }^{39}$ It is assumed that the Roman epithet 'Pauleia' originated from Paullus Fabius

\footnotetext{
${ }^{36}$ Robert 1939, 245-248 (OMS I p. 629-632) = IAlexandreia Troas 52, 53 and 54. In addition to these inscriptions, CIG 3620 (= IAlexandreia Troas 50) honoring an unknown athlete may have concerned the Smintheia Pauleia games, Frisch 1974, 38-39. On the preserved part of a statue base at Çanakkale Archaeological Museum, listing the victories of an athlete and attesting to games called Smintheia held in

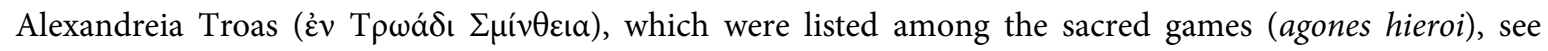
Taşlıklığlu 1971, 179 no. 7 (BE 1972, 366) = IIlion 125. From an inscription at Messene in the southwestern Peloponnese, honoring Sosias who won the men's diaulos at Smintheia, it appears that the Smintheia were organized in Alexandreia Troas even during the Late Hellenistic period, see Habicht 2000, 123-126; Gauthier 2000, 631-635. It gives me great pleasure to reveal that during the field seasons of 2009-2013 approximately 20 very well preserved statue bases were discovered in Smintheion bearing honorary inscriptions of the victorious athletes at the Smintheia (Pauleia) games. These findings will be published in the near future.

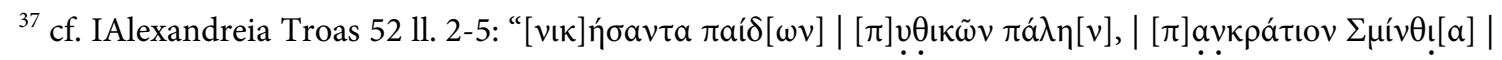

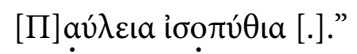

${ }^{38}$ IAnazarbos 68: "D(is) M(anibus). Calventio Silvano, veteran(o) ex numero e\{x\}quitum Batavonum etc." For the nomen Calventius, see TLL, Onomasticon II s.v. Calventius; Schulze 1966, 139; Tataki 2006, 161 no. 125.

${ }^{39}$ IAlexandreia Troas 52 and 53.
} 
Maximus, who was proconsul of Asia Minor during the reign of Augustus. ${ }^{40}$ However, Louis Robert believed that the epithet was adjoined to Smintheia in order to honor a benefactor bearing the name of Paulus, who financed the Smintheia Games and who may have lived in Colonia Augusta Troadensis in a later period. ${ }^{41}$ The epithet isopythios in line five, meaning "equal to the Pythian Games," indicates that the games at Smintheia Pauleia were ranked equally with those held at Pythia in Delphi, including in terms of the awards and privileges. ${ }^{42}$

\section{Bibliography}

Abmeier 1990

A. Abmeier, Neue Grabinschriften, in: Ü. Serdaroğlu - R. Stupperich - E. Schwertheim (edd.), Ausgrabungen in Assos, Bonn 1990, 23-28 (Asia Minor Studien 2).

Arslan - Özhan 2013

N. Arslan - T. Özhan, Tiyatro Yazıtları Işı̆̆ında Assos'ta Zanaatkârlar, Belleten LXXVII/278, 2013, 73-80.

Brandt 1992

H. Brandt, Gesellschaft und Wirtschaft Pamphyliens und Pisidiens im Altertum, Bonn 1992 (Asia Minor Studien 7).

Breccia 1911

E. Breccia, Inscrizioni Greche e Latine, Caire 1911 (Catalogue géneral des antiquités égyptiennes du Musée d'Alexandrie).

Dunand 1973

F. Dunand, Le Culte d'Isis dans le Bassin Oriental de la Méditerranée, III. Le culte d'Isis en Asie Mineure Clerge et Rituel des Sanctuaires Isiaques, Leiden 1973.

Frisch 1974

P. Frisch, Zwei Athleteninschriften aus der Troas, ZPE 13, 1974, 38-39.

Frisch 1988

P. Frisch, Die Klassifikation der ПAI $\Delta \mathrm{E} \Sigma$ bei den griechischen Agonen, ZPE 75, 1988, 179-185.

Ful 2009

Ş. D. Ful, A Dedication to Isis and Sarapis, EA 42, 2009, 101.

Gauthier 2000

P. Gauthier, Inscription Agonistique de Messène, REG 113, 2000, 631-635.

Habicht 2000

C. Habicht, Neues aus Messene, ZPE 130, 2000, 121-126.

Judeich 1898

W. Judeich, Skepsis, in: Beiträge zur Alten Geschichte und Geographie. Festschrift für Heinrich Kiepert, Berlin 1898, 224-240.

Klee 1918

T. Klee, Zur Geschichte der Gymnischen Agone an Griechischen Festen, Berlin 1918.

Pleket 2014a

H. W. Pleket, Inscriptions as Evidence for Greek Sport, in: P. Christesen - D. G. Kyle (edd.), A Companion to Sport and Spectacle in Greek and Roman Antiquity, Malden, MA/Oxford/Chichester 2014, 98-111.

Pleket 2014b

H. W. Pleket, Sport in Hellenistic and Roman Asia Minor, in: P.

\footnotetext{
${ }^{40}$ IGR IV 244: "Ludi instituti in honorem Apollonis Sminthii ... et Pauli Fabii Maximi, cos. anno 11. ante C. n. etc.”

${ }^{41}$ Robert 1939, 247 (OMS I p. 631).

${ }^{42}$ Pleket 2014a, 103; Pleket 2014b, 367; cf. also Frisch 1988, 181.
} 
Robert 1939

Schulze 1966

Stupperich 1992

Stupperich 1993

Taşliklığlu 1971

Tataki 2006

van Nijf 1997
Christesen - D. G. Kyle (edd.), A Companion to Sport and Spectacle in Greek and Roman Antiquity, Malden, MA/Oxford/Chichester 2014, 364-320.

L. Robert, Inscriptions grecques d'Asie Mineure, in: W. M. Calder - J. Keil (edd.), Anatolian Studies presented to William Hepburn Buckler, Manchester 1939, 227-248.

W. Schulze, Zur Geschichte lateinischer Eigennamen, Berlin/Zurich/Dublin 1966.

R. Stupperich, Zweiter Vorbericht über die Grabung in der Westtor-Nekropole von Assos im Sommer 1990, in: Ü. Serdaroğlu - R. Stupperich (edd.), Ausgrabungen in Assos 1990, Bonn 1992, 1-31 (Asia Minor Studien 5).

R. Stupperich, Dritter Vorbericht über die Grabung in der Westtor-Nekropole von Assos im Sommer 1991, in: Ü. Serdaroğlu - R. Stupperich (edd.), Ausgrabungen in Assos 1991, Bonn 1993, 1-35 (Asia Minor Studien 10).

Z. Taşlıklığlu, Trakya'da Epigrafya Araştırmaları II, İstanbul 1971.

A. B. Tataki, The Roman Presence in Macedonia, Athens 2006

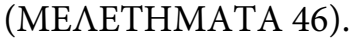

O. van Nijf, The Civic World of Professional Associations in the Roman East, Amsterdam 1997 (Dutch Monographs on Ancient History and Archaeology 17). 


\section{Assos'tan Beş Yazıt Fragmanı Özet}

Makalede Çanakkale ili sınırları içerisindeki Assos kazı evinin deposunda bulunan beş adet yazıt fragmanı tanıtılmaktadır. Bunlardan ilki, daha önce Assos'tan bir onurlandırma dekretinde yargıç olarak adı kayda geçmiş Kleomortos oğlu Latimos adlı kişiyi onurlandıran bir dekretten günümüze kalan satırlardır. İkinci fragmanın Killaios adlı bir kişinin mezar yazıtı olduğu anlaşılmaktadır. Üçüncü yazıt, büyük olasılıkla bir mezar yazıtının parçasıdır. Dördüncü yazıt, Ariston oğlu Menophantos tarafından Tanrıça Isis'e sunulmuş bir adak yazıtıdır ve bu yazıt, Assos'ta bir Mısır kültünün varlığına dair ilk sağlam kanıttır. Bu yazıtla birlikte, Sarapis kültü müritlerinin topluluğu ile ilişkili olabilecek, Assos tiyatrosundan bir topos yazıtı da tanıtılmıştır. Beşinci yazıtta, Aleksandreia Troas kenti tarafından Apollon Smintheus onuruna düzenlenen Smintheia Pauleia spor oyunlarında çocuklar kategorisinde pankration dalında zafere ulaşmış Lucius Calventius Faustinus onurlandırılmaktadır. Yazıtların Türkçe çevirileri şu şekildedir:

No. 1: Kleomortos oğlu Latimos... daha önceki bir zamanda... birçok işler ve...

No. 2: ... Killaios için.

No. 3: Bu yazıt büyük oranda tahrip olduğundan kesin bir çeviri vermek mümkün değildir.

No. 4: Ariston oğlu Menophantos, Isis'e [adadi].; Sarapis kültü müritleri

No. 5: Pythia oyunlarına eş Smintheia Pauleia (oyunlarında), çocukların yarıştığı pankration'u kazanan Lucius Calventius Faustinus'u [filanca kişi onurlandırdı].

Anahtar Sözcükler: Assos; Kleomortos; Isis; Sarapiastai; Mısır kültleri; Smintheia Pauleia; Killaios.

\section{Five Fragmentary Inscriptions from Assos}

\section{Abstract}

In this article, five fragmentary inscriptions are presented from the depository of the Assos excavation house in Çanakkale province, Turkey. The first inscription is the surviving part of a decree honoring Latimos, son of Cleomortos, whose name was recorded as a judge in another honorary decree from Assos. The second fragment appears to be the epitaph of an individual bearing the name 'Cillaios'. The third inscription is most probably the surviving fragment of an epitaph. The fourth inscription is a dedication to Isis, offered by Menophantos, son of Ariston, and is the first secure evidence of the presence of an Egyptian cult in the vicinity of Assos. A seating inscription from the Assos theater, which may be a reference to the cult association of the Sarapis-devotees of Assos, is also presented. The fifth fragment honors Lucius Calventius Faustinus, who won the boys' pankration in the Smintheia Pauleia athletic games held by the ancient city of Alexandreia Troas in honor of Apollo Smintheus.

Keywords: Assos; Cleomortos; Isis; Sarapiastai; Egyptian cults; Smintheia Pauleia; Cillaios. 


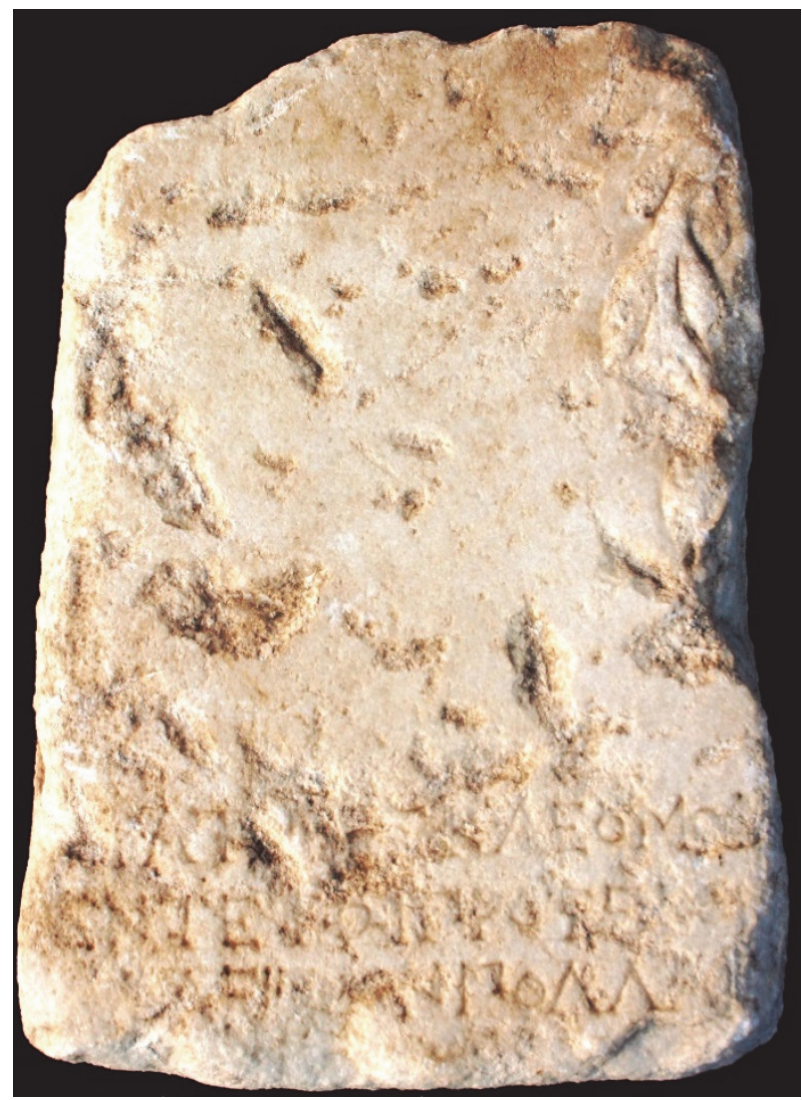

Fig. 1

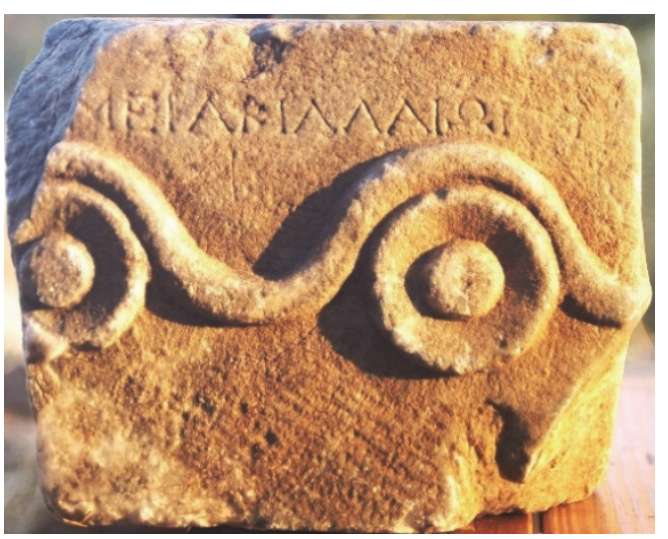

Fig. 2

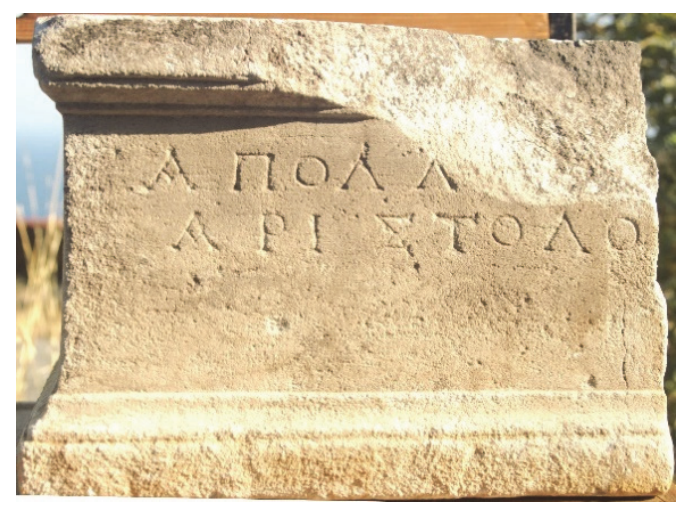

Fig. 3

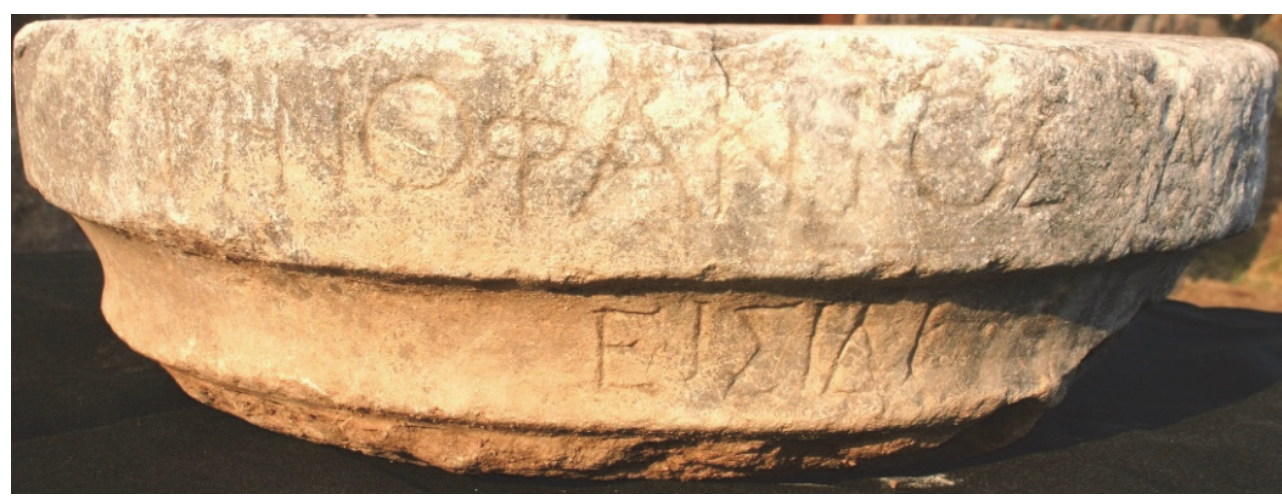

Fig. 4

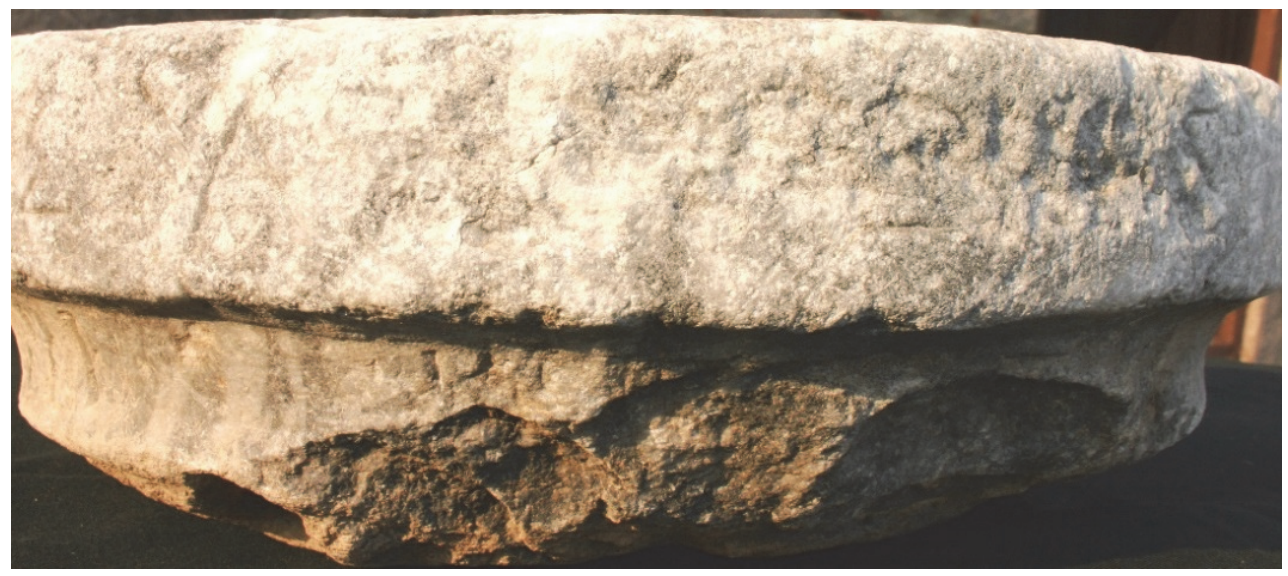

Fig. 5 


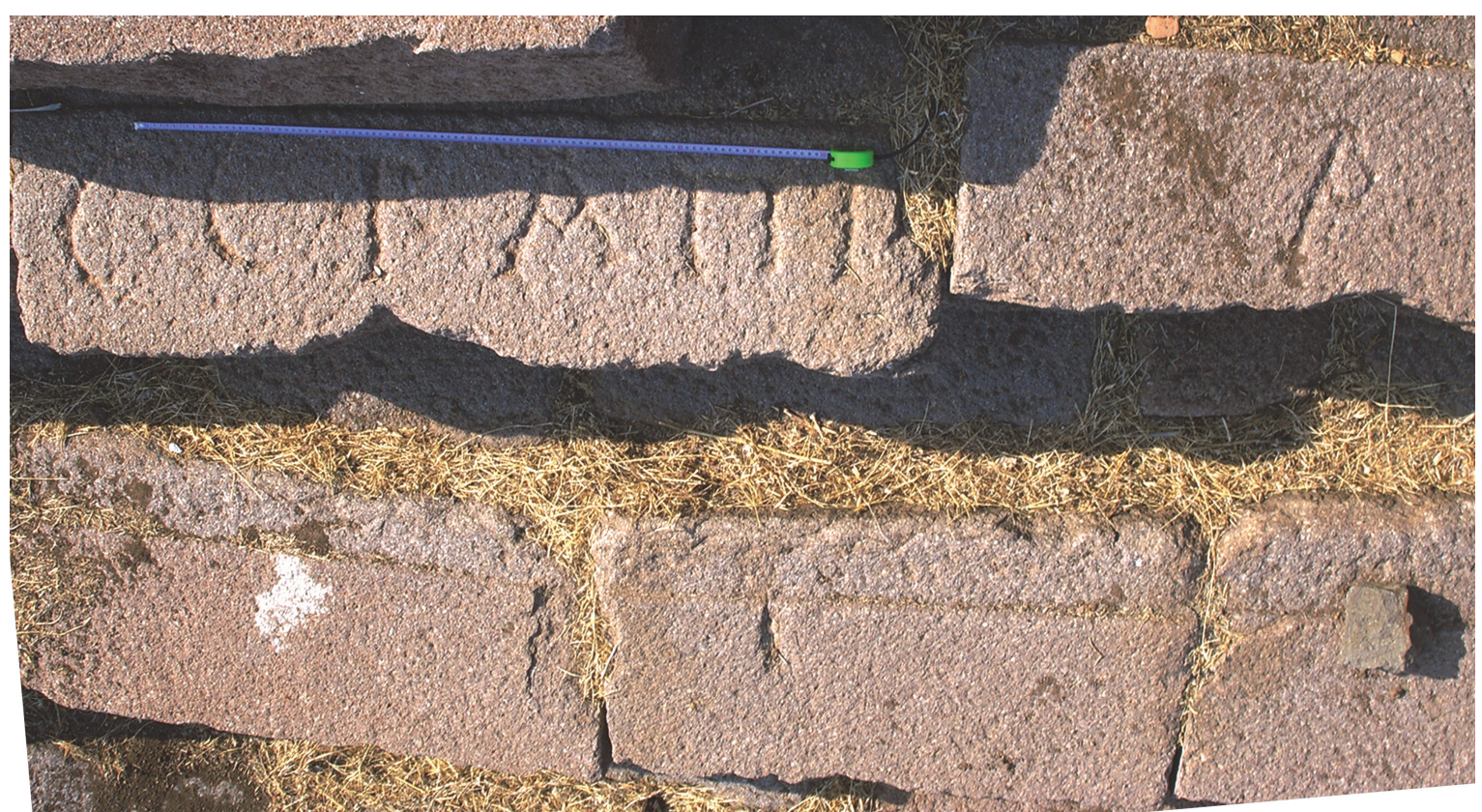

Fig. 6

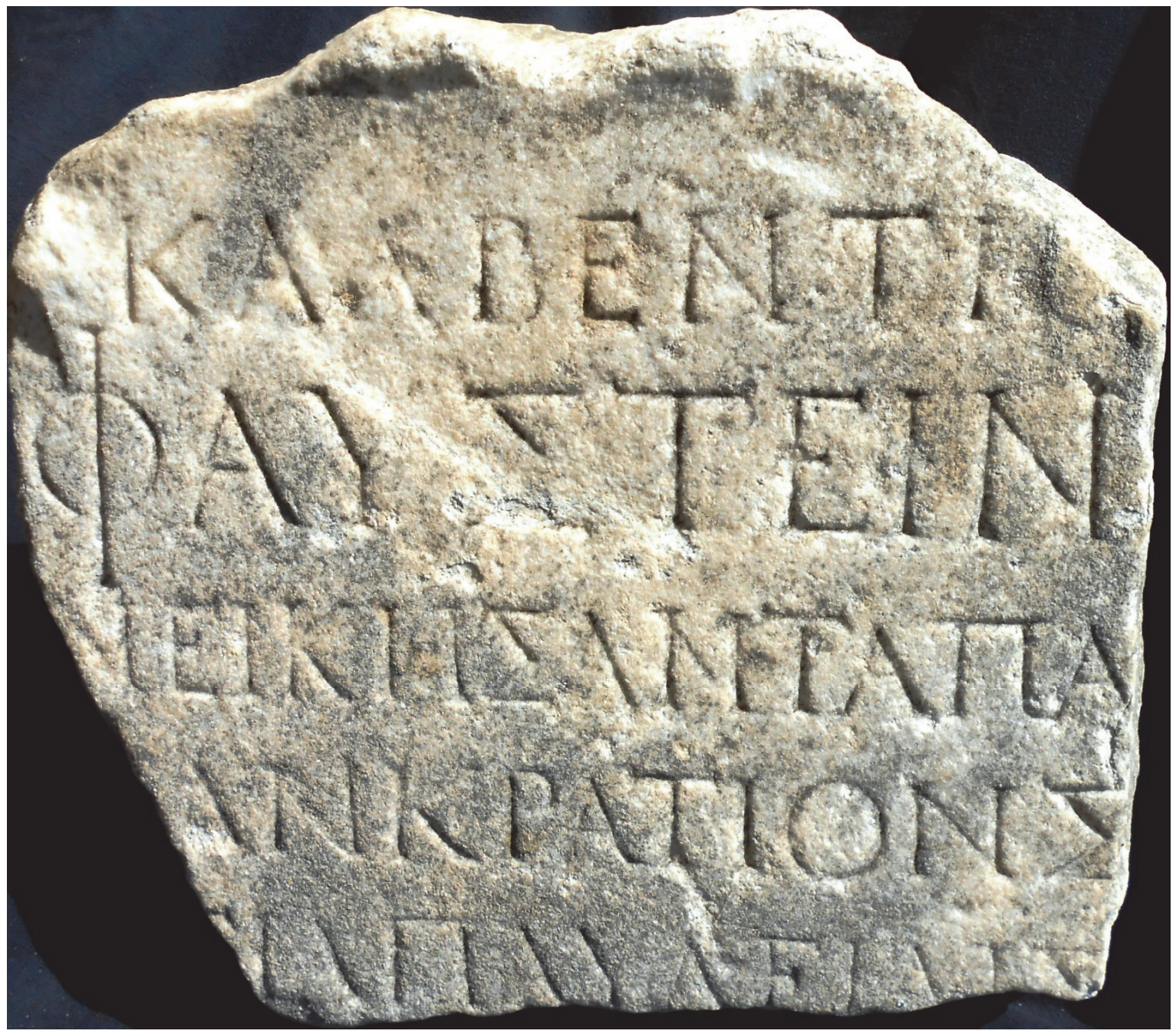

Fig. 7 